\title{
PENGARUH MODEL PEMBELAJARAN KUANTUM DAN TEKNIK MERANGKUM TERHADAP PENALARAN MAHASISWA
}

\author{
I Gede Astawan dan Ni Wayan Rati \\ FMIPA Universitas Pendidikan Ganesha \\ Email: igedeastawan@yahoo.com
}

\begin{abstract}
Abstrak: Penelitian ini bertujuan mengetahui: (1) perbedaan penalaran mahasiswa antara kelompok model pembelajaran kuantum dan pembelajaran konvensional; (2) perbedaan penalaran mahasiswa antara kelompok merangkum dengan teknik peta pikiran dan teknik konvensional; dan (3) interaksi antara model pembelajaran dan teknik merangkum terhadap penalaran mahasiswa. Jenis penelitian adalah kuasi eksperimen. Populasi penelitian adalah mahasiswa semester II Jurusan PGSD FIP Undiksha. Sampel diambil dengan teknik random. Data yang dikumpulkan adalah penalaran mahasiswa dengan tes penalaran. Data dianalisis dengan anava dua jalan faktorial $2 \times 2$.Temuan penelitian menunjukkan hal-hal sebagai berikut. (1) Terdapat perbedaan penalaran mahasiswa antara kelompok model pembelajaran kuantum dan kelompok pembelajaran konvensional. (2) Terdapat perbedaan penalaran mahasiswa antara kelompok merangkum dengan teknik peta pikiran dan teknik konvensional. (3) Terdapat interaksi antara model pembelajaran dan teknik merangkum terhadap penalaran mahasiswa. Berdasarkan temuan penelitian tersebut disarankan dosen untuk menggunakan model pembelajaran kuantum dan merangkum dengan teknik peta pikiran dalam rangka meningkatkan penalaran mahasiswa.
\end{abstract}

\section{Kata-kata kunci: pembelajaran kuantum, teknik merangkum, penalaran}

\section{THE EFFECT OF QUANTUM LEARNING MODEL AND SUMMARIZING TECHNIQUESON STUDENT'S REASONING}

\begin{abstract}
This research is aimed at investigating (1) the difference between the reasoning of students applying quantum learning model and that of students applying group conventional learning model; (2) the difference between the reasoning of students summarizing by mind and that of students summarizing conventionally; and (3) the interaction between learning models,summarizing techniques and student's reasoning. Deploying quasi experiment, this research recruited the second semester students of Primary Teacher Education Department, Ganesha University of Education, through random sampling technique. The data were in the form of the results of reasoning test. The data were analysed using two way factorial of anova $2 \times 2$. The research findings show that (1) difference is found between the reasoning of students applying group quantum learning model and that of students applying conventional learning model; (2) difference is found between the reasoning of students summarizing by mind and that of students summarizing conventionally; and (3) there is interaction between learning models, summarizing techniques and student's reasoning. It is thus suggested that lecturers should apply quantum learning model and summarizing technique by mind in order to increase student's reasoning.
\end{abstract}

Key words: quantum learning, summarize technique, reasoning

\section{PENDAHULUAN}

Pendidikan selalu menjadi topik hangat bagi setiap negara di dunia. Hal ini tentu dapat dimengerti karena melalui pendidikan suatu bangsa dapat berkembang dan menjadi negara maju. Indonesia, sampai saat ini masih ketinggalan jauh mutu pendidikannya dibandingkan negara-negara maju dan negara-negara berkembang di dunia. Nilan (2009:141) mengungkapkan bahwa mutu pendidikan Indonesia lebih rendah dari negara tetangganya di Asia Tenggara, yaitu Malaysia dan Thailand. Rendahnya mutu pendidikan berimplikasi pada rendahnya pula sumber daya manusia (SDM). Rendahnya SDM bermuara pada kurang kompetitifnya bangsa Indonesia menghadapi persaingan di era global. Degeng (2001:7) dan Fullan (2005:50) menyatakan bahwa manusia yang dapat 'hidup' di abad ke-21 adalah 
manusia yang kompetitif, cerdas, dan siap menghadapi perubahan. Pendidikan dapat dijadikan sarana untuk melahirkan SDM yang berkualitas (Wiratma, 2010:110; Wedell, 2009:12; Pring, 2005:2). Sehubungan dengan hal tersebut, dunia pendidikan mendapatkan sorotan yang sangat tajam berkaitan dengan upaya menciptakan SDM berkualitas. Peningkatan SDM berkualitas salah satunya dapat dilakukan dengan meningkatkan mutu pendidikan IPA.

Berbagai upaya telah dilakukan pemerintah untuk meningkatkan mutu pendidikan IPA, seperti 1) pengembangan model-model pembelajaran IPA, 2) pengembangan media pembelajaran IPA, 3) penataran bagi pendidik, 4) penyediaan sarana-prasarana yang menunjang pembelajaran IPA, dan 5) seminar dan pelatihan. Akan tetapi, semua hal tersebut belum menunjukkan hasil yang menggembirakan. Trends International Mathematics and Sciences Study (TIMSS), lembaga yang mengukur hasil pendidikan di dunia, melaporkan bahwa kemampuan matematika dan sains peserta didik SD Indonesia berada pada peringkat ke-32 dari 38 negara (Nurhadi, et al., 2004:12). Konsorsium Pendidikan Indonesia, 2010:1), melaporkan bahwa dalam bidang matematika dan IPA, Indonesia masuk peringkat 32 dari 36 negara. Fakta-fakta tersebut, menunjukkan bahwa kualitas pembelajaran perlu ditingkatkan, karena pembelajaran IPA memegang peranan penting dalam meningkatkan kualitas SDM.

De Porter et al. (2003:25) mengungkapkan bahwa pengaturan lingkungan belajar sangat berperan dalam menciptakan suasana belajar yang nyaman, salah satunya pengaturan meja belajar. Beberapa pola pengaturan meja yang disarankan, seperti berbentuk U, melingkar, atau setengah lingkaran. Dengan demikian, mahasiswa memiliki peluang yang sama untuk berinteraksi satu sama lain, termasuk dengan dosennya. Ketiga, mahasiswa mengalami kesulitan dalam mempelajari konsep IPA. Hal ini didukung dari hasil wawancara dengan mahasiswa. Mahasiswa mengaku bahwa salah satu mata kuliah yang dipandang sulit adalah IPA. Hal ini disebabkan oleh ketidaktahuan mereka terhadap manfaat yang mereka peroleh dari belajar IPA. Keempat, kurangnya pengorganisasian materi yang sesuai dengan cara kerja otak. Otak tidak diransang untuk berpikir imajinatif dan kreatif. Hal ini menyebabkan otak tidak bekerja optimal. Cara mengoptimalkan kerja otak adalah dengan menggunakan metode peta pikiran.
Berdasarkan uraian di atas, sebagai tenaga pendidik, khususnya yang mengasuh mata kuliah IPA, hendaknya mengupayakan agar IPA tidak menjadi momok dan menakutkan di mata mahasiswa. Untuk itu, diperlukan suatu upaya dalam rangka meningkatkan kemampuan penalaran. Salah satunya adalah dengan mengemas pembelajaran yang inovatif, yang dapat menyediakan situasi belajar secara kondusif dan menyenangkan serta dapat membantu mahasiswa mengatasi miskonsepsinya, sehingga konsepsi mahasiswa menjadi konsep ilmiah. Salah satu pembelajaran yang relevan untuk hal tersebut adalah pembelajaran kuantum. Pembelajaran kuantum berupaya menumbuhkan minat belajar mahasiswa dengan mengaitkan materi pelajaran (konten) dengan kehidupan sehari-hari (konteks) (De Porter, et al., 2003:19; De Porter, 2008:5).

Pembelajaran yang dapat mengaitkan materi dengan kehidupan nyata, menjadikan pembelajaran tersebut bermakna. Hal ini sesuai dengan teori belajar bermakna David Ausubel (Arends \& Kilcher, 2010; Joyce, et al., 2009:281) bahwa belajar akan bermakna apabila pebelajar dapat mengaplikasikan pelajarannya dalam kehidupan nyata.

Dengan adanya kegiatan merangkum, akan dapat memastikan bahwa konsep-konsep yang dipelajari lebih dipahami dengan baik. Merangkum dapat memfokuskan pikiran pada bagianbagian yang menjadi konsep esensial.

Berbagai kajian, baik teoretik maupun empirik, menunjukkan bahwa pembelajaran kuantum sangat efektif diterapkan dalam pembelajaran. Herdian (2009:1) menyatakan bahwa pembelajaran kuantum dapat mengembangkan potensi diri, kemampuan pikiran, dan motivasi karena meniadakan hukuman dan hadiah dan menggantinya menjadi setiap usaha dihargai serta kesalahan dipandang sebagai sesuatu yang manusiawi. De Porter, et al. (2003:50) mengungkapkan bahwa penerapan pembelajaran kuantum telah membawa sukses besar bagi sekolah dan anak didiknya. Pembelajaran kuantum juga efektif diterapkan dalam pembelajaran matematika (Astawa, 2004:10; Suarjana dan Japa, 2012:35; Suarjana, 2013:38).

Pembelajaran kuantum (quantum teaching) selalu berpegang pada asas "bawalah dunia mereka ke dunia kita dan antarkan dunia kita ke dunia mereka" (De Porter, et al., 2003:9). Hal ini menyatakan bahwa sebagai langkah pertama yang 
perlu dipikirkan oleh pendidik adalah pentingnya memasuki dunia peserta didik. Pada hakikatnya, pendidik untuk memperoleh hak mengajar hendaknya membangun jembatan outentik memasuki dunia peserta didik (Meier, 2000:61). Asas quantum teaching tersebut memberikan makna bahwa pembelajaran yang dilaksanakan harus memperhatikan pengetahuan awal peserta didik. Pendidik, bertugas memfasilitasi peserta didik untuk mengubah pengetahuan awal yang berlabel miskonsepsi menjadi konsep ilmiah (Clayton, et al., 2010:351). Untuk dapat memfasilitasinya, pembelajaran hendaknya berpusat pada peserta didik (student centered). Jadi, mengajar harus selalu dikaitkan dengan belajar yang merupakan full-contact action yang senantiasa melibatkan semua aspek kepribadian manusia-pikiran, perasaan, bahasa tubuh, pengetahuan, sikap awal, dan persepsi masa mendatang.

Pembelajaran kuantum (quantum teaching) berfokus pada hubungan dinamis dalam lingkungan belajar dan interaksi yang membangun landasan dan kerangka yang kuat untuk belajar. Tiga kata kunci yang dapat dijadikan sandaran dalam pembelajaran kuantum dengan format dinamis, yaitu quantum, pemercepatan belajar, dan fasilitasi (De Porter, et al., 2003:19; De Porter \& Hernacki, 2003:76).

Quantum adalah interaksi yang mengubah energi menjadi cahaya (De Porter, et al., 2003:19; A'la, 2010:7). Dalam konteks pembelajaran, istilah quamtum diadopsi menjadi quantum teaching. Quantum teaching adalah penggubahan bermacam-macam interaksi yang ada di dalam dan di sekitar momen belajar. Interaksi-interaksi tersebut mencakup unsur-unsur untuk belajar efektif yang dapat mengubah kemampuan dan bakat alamiah peserta didik menjadi cahaya yang akan bermanfaat bagi mereka dan bagi orang lain dan dapat memengaruhi kesuksesan peserta didik dalam belajar. Percepatan belajar adalah upaya menyingkirkan hambatan yang menghalangi proses belajar alamiah dengan secara sengaja menggunakan instrumen yang dapat mewarnai lingkungan sekeliling, pengemasan bahan pembelajaran yang sesuai, cara penyajian yang efektif, dan keterlibatan aktif.

Dalam konteks pembelajaran, upaya yang dapat dilakukan adalah menggunakan berbagai media, musik, alat peraga, dan lain-lain. Fasilitasi adalah suatu upaya yang merujuk kepada implementasi strategi yang dapat menyingkirkan hambatan belajar peserta didik, mengembalikan proses belajar ke keadaannnya yang menarik dan alami. Strategi yang dapat digunakan misalnya disesuaikan dengan gaya belajar siswa, yaitu visual, auditorial, dan kinestetik. Anak difasilitasi dengan media audiovisual dan diberikan kesempatan melakukan demonstrasi sendiri.

\section{METODE}

Penelitian ini mengikuti desain penelitian kuasi eksperimen dengan rancangan non-equivalent post test only control group design (Campbell $\&$ Stanley, 1996:25). Populasi dalam penelitian ini adalah mahasiswa semester II Jurusan PGSD FIP Undiksha. Jumlah kelas keseluruhannya adalah 7 kelas. Berdasarkan karakteristik populasi dan tidak bisa dilakukannya pengacakan individu, maka pengambilan sampel pada penelitian ini dilakukan dengan teknik random sampling unit kelas.

Data yang dikumpulkan adalah penalaran mahasiswa dengan tes penalaran. Penalaran terdiri dari tiga dimensi, yaitu data keterampilan berpikir dasar, keterampilan berpikir kritis, dan keterampilan berpikir kreatif (Marzano, et al., 1998:28). Data dianalisis dengan menggunakan anava dua jalan faktorial 2 × 2 (Candiasa, 2004: 118). Sebelum dilakukan analisis data, terlebih dahulu dilakukan pengujian normalitas dan homogenitas data sebagai uji prasyarat. Pengujian normalitas sebaran data digunakan statistik Kolmogrov Test dan Shapiro-Wilks Test (Candiasa, 2004:118). Kriteria pengujian: data memiliki sebaran distribusi normal jika angka signifikansi yang dihasilkan lebih besar dari 0,05 dan dalam hal lain data tidak berdistribusi normal. Uji homogenitas varians antar kelompok menggunakan Levene's test of Equality of Error Variansce (Candiasa, 2004:119). Uji normalitas dan homogenitas dilakukan dengan memanfaatkan bantuan SPSS statistic 17.0.

\section{HASIL DAN PEMBAHASAN Hasil}

Secara deskriptif hasil penelitian ini dapat dipilah menjadi dua, yakni menurut model pembelajaran dan menurut teknik merangkum. Menurut model pembelajaran hasil penelitian menunjukkan bahwa nilai penalaran yang dicapai mahasiswa untuk kelompok model pembelajaran kuantum (MPKu) mulai dari 60,00 sampai dengan 91,00 dan untuk model pembelajaran konvensional (MPKo) bergerak dari 46,70 sampai 
dengan 84,80. Distribusi frekuensi dan persentase penalaran mahasiswa menurut model pembelajaran disajikan pada Tabel 1.

Tampak bahwa kualifikasi distribusi frekuensi dan persentase nilai penalaran mahasiswa kelompok MPKu lebih tinggi dibandingkan kelompok MPKo. Sebaran nilai penalaran mahasiswa kelompok MPKu lebih baik dibandingkan kelompok MPKo.

Nilai rata-rata $(\overline{\mathrm{X}})$ dan standar deviasi $(\mathrm{SD})$ penalaran mahasiswa menurut model pembelajaran disajikan pada Tabel 2.

Hasil tersebut menunjukkan bahwa secara deskriptif kelompok yang belajar menggunakan model pembelajaran kuantum lebih tinggi dibandingkan dengan kelompok yang belajar menggunakan model pembelajaran konvensional.

Dalam hal teknik merangkum hasil penelitian menunjukkan bahwa nilai penalaran yang dicapai mahasiswa untuk kelompok merangkum teknik peta pikiran (TPP) mulai dari 62,00 sampai dengan 95,00 dan untuk kelompok merangkum teknik konvensional (TK) bergerak dari 62,50 sampai dengan 83,50. Distribusi frekuensi dan persentase berdasarkan tingkat penguasaan materi nilai penalaran mahasiswa dibuat berdasarkan konversi nilai absolut skala lima dan berdasarkan data nilai post test yang diperoleh. Distribusi dan persentase penalaran menurut teknik merangkum disajikan pada Tabel 3.

Oleh karena itu, dapat dinyatakan bahwa kualifikasi distribusi penalaran mahasiswa untuk kelompok merangkum TPP lebih tinggi dibandingkan kelompok merangkum TK. Sebaran nilai kelompok merangkum TPP lebih baik dibandingkan kelompok merangkum TK.

Nilai rata-rata () dan standar deviasi (SD) hasil post test pada setiap kelompok teknik merangkum, disajikan pada Tabel 4.

Hasil tersebut menunjukkan bahwa secara deskriptif kelompok yang belajar menggunakan teknik merangkum peta pikiran lebih tinggi dibandingkan dengan kelompok yang belajar menggunakan teknik konvensional.

Tabel 1. Distribusi frekuensi dan persentase nilai penalaran mahasiswa

\begin{tabular}{cccccc}
\hline \multirow{2}{*}{ Nilai } & \multirow{2}{*}{ Kualifikasi } & \multicolumn{3}{c}{ MPKu } & \multicolumn{2}{c}{ MPKo } \\
\cline { 3 - 6 } & & Fo & Persentase (\%) & Fo & Persentase (\%) \\
\hline $85,0-100$ & Sangat tinggi & 7 & 20,59 & 0 & 00,00 \\
$70,0-84,9$ & Tinggi & 22 & 64,71 & 21 & 61,76 \\
$55,0-69,9$ & Cukup & 5 & 14,70 & 10 & 29,41 \\
$40,0-54,9$ & Kurang & 0 & 00,00 & 3 & 8,83 \\
$0,00-39,9$ & Sangat Kurang & 0 & 00,00 & 0 & 0 \\
& Jumlah & 34 & 100 & 34 & 100 \\
\hline
\end{tabular}

Keterangan: $\mathrm{Fo}=$ Frekuensi observasi, $\mathrm{MPKu}=$ Model pembelajaran kuantum, MPKo $=$ Model pembelajaran konvensional

Tabel 2. Nilai rata-rata dan standar deviasi data penalaran

\begin{tabular}{lcccccc}
\hline Variabel & \multicolumn{2}{c}{ KLP MPKu } & \multicolumn{2}{c}{ KLP MPKo } & \multicolumn{2}{c}{ TOTAL } \\
\cline { 2 - 7 } & $\overline{\mathrm{X}}$ & SD & $\overline{\mathrm{X}}$ & SD & $\overline{\mathrm{X}}$ & SD \\
\hline PM & 76,85 & 8,18 & 70,875 & 9,08 & 73,86 & 9,09 \\
\hline
\end{tabular}

Keterangan: $\mathrm{PM}=$ penalaran mahasiswa, KLPMPKu= kelompok model pembelajaran kuantum, KLPMPKo= kelompok model pembelajaran konvensional, = nilai rata-rata, dan $\mathrm{SD}=$ standar deviasi.

Tabel 3. Distribusi frekuensi dan persentase nilai penalaran mahasiswa

\begin{tabular}{cccccc}
\hline \multirow{2}{*}{ Nilai } & \multirow{2}{*}{ Kualifikasi } & \multicolumn{2}{c}{ TPP } & \multicolumn{2}{c}{ TK } \\
\cline { 3 - 6 } & & Fo & Persentase (\%) & Fo & Persentase (\%) \\
\hline $85,0-100$ & Sangat tinggi & 4 & 8,00 & 0 & 00,00 \\
$70,0-84,9$ & Tinggi & 37 & 74,00 & 36 & 72,00 \\
$55,0-69,9$ & Cukup & 9 & 18,00 & 14 & 28,00 \\
$40,0-54,9$ & Kurang & 0 & 00,00 & 0 & 0 \\
$0,00-39,9$ & Sangat Kurang & 0 & 00,00 & 0 & 0 \\
\multicolumn{2}{c}{ Jumlah } & 50 & 100 & 50 & 100 \\
\hline
\end{tabular}

Keterangan: $\mathrm{Fo}=$ frekuensi observasi, $\mathrm{TPP}=$ teknik peta pikiran, $\mathrm{TK}=$ teknik konvensional 
Tabel 4. Nilai rata-rata dan standar deviasi data penalaran

\begin{tabular}{lcccccc}
\hline Variabel & \multicolumn{2}{c}{ KLP MTPP } & \multicolumn{2}{c}{ KLP MTK } & \multicolumn{2}{c}{ TOTAL } \\
\cline { 2 - 7 } & $\bar{X}$ & SD & $\bar{X}$ & SD & $\bar{X}$ & SD \\
\hline PM & 75,55 & 6,70 & 73,38 & 6,03 & 74,46 & 6,43 \\
\hline
\end{tabular}

Keterangan : PM= penalaran mahasiswa, KLPMTPP $=$ kelompok merangkum teknik peta pikiran, KLPMTK = kelompok merangkum teknik konvensional, = nilai rata-rata, $\mathrm{SD}=$ standar deviasi

Tabel 5. Ringkasan Hasil Uji Anava Dua Jalan faktorial 2 x 2

\begin{tabular}{rrrrrrrrr}
\hline Source & $\begin{array}{r}\text { Type III Sum of } \\
\text { Squares }\end{array}$ & df & Mean Square & F & Sig. & $\begin{array}{r}\text { Eta } \\
\text { Squared }\end{array}$ & $\begin{array}{r}\text { Noncent. } \\
\text { Parameter }\end{array}$ & $\begin{array}{r}\text { Observed } \\
\text { Power }\end{array}$ \\
\hline Corrected & $1307.047^{\mathrm{a}}$ & 3 & 435.682 & 14.964 & .000 & .319 & $1307.047^{\mathrm{a}}$ & 3 \\
Model & & & & & & & & \\
Intercept & 554503.623 & 1 & 554503.623 & 19045.018 & .000 & .995 & 554503.623 & 1 \\
MP & 142.803 & 1 & 142.803 & 4.905 & .029 & .049 & 142.803 & 1 \\
TM & 117.723 & 1 & 117.723 & 4.043 & .047 & .040 & 117.723 & 1 \\
MP * TM & 1046.523 & 1 & 1046.523 & 35.944 & .000 & .272 & 1046.523 & 1 \\
Error & 2795.080 & 96 & 29.115 & & & & 2795.080 & 96 \\
Total & 558605.750 & 100 & & & & & 558605.750 & 100 \\
Corrected & 4102.127 & 99 & & & & & 4102.127 & 99 \\
Total & & & & & & & & \\
\hline
\end{tabular}

Keterangan: $\mathrm{MP}=$ Model pembelajaran, $\mathrm{TM}=$ Teknik merangkum

Ringkasan hasil terhadap uji hipotesis dengan menggunakan program SPSS statistics 17.0 disajikan pada Tabel 5.

Berdasarkan data pada Tabel 5 dapat ditarik interpretasi sebagai berikut. Pertama, terdapat perbedaan penalaran mahasiswa antara kelompok yang belajar dengan MPKu dan kelompok yang belajar menggunakan MPKo. Kelompok MPKu lebih baik dibandingkan kelompok MKo. Kedua, terdapat perbedaan penalaran mahasiswa antara kelompok merangkum dengan TPP dan kelompok merangkum dengan TK. Ketiga, terdapat pengaruh interaktif antara variabel-variabel model pembelajaran dan variabel-variabel teknik merangkum terhadap penlaran mahasiswa.

\section{Pembahasan}

Hasil penelitian menunjukkan bahwa terdapat perbedaan penalaran mahasiswa yang signifikan antara kelompok yang belajar dengan MPKu dan kelompok yang belajar dengan MPKo. Pencapaian penalaran mahasiswa kelompok MPKu lebih tinggi dibandingkan dengan kelompok MPKo. Dengan kata lain, bahwa model pembelajaran MPKu lebih unggul dibandingkan dengan MPKo dalam pencapaian PM. Tetapi, secara deskriptif level PM ini belum mencapai standar keberhasilan yang memadai.

Secara operasional empiris dalam pencapaian PM, MPKu lebih unggul daripada MPKo. Hal ini sejalan dengan kajian teoretis yaitu dasar filosofis pembelajaran kuantum adalah paham konstruktivisme yang menyatakan bahwa pebelajar membangun pengetahuan dalam benaknya sendiri. Paham konstruktivisme juga menyatakan bahwa pebelajar telah memiliki pengetahuan awal yang mereka peroleh dari pengalaman sehari-hari dan jenjang pendidikan sebelumnya. Pendidik dapat menjembatani antara pengetahuan awal pebelajar dengan pengetahuan ilmiah yang akan dibelajarkan.

Keadaan ini dapat dimisalkan dengan pendidik menyediakan tangga yang dapat membantu peserta didik untuk mencapai tingkatan pemahaman yang lebih tinggi, namun harus diupayakan agar pebelajar sendiri yang memanjat tangga tersebut. Implementasi pembelajaran kuantum di kelas dimulai dengan penyampaian pertanyaan dan pernyataan kepada mahasiswa dan atau memberikan fenomena kontekstual yang dekat dengan lingkungan di sekeliling mahasiswa. Pertanyaan awal yang disuguhkan kepada mahasiswa adalah pertanyaan yang kontekstual, yaitu pertanyaan yang aktual yang ada di sekitar lingkungannya dan relevan dengan materi yang diharapkan dapat dikuasai oleh mahasiswa.

Pertanyaan, pernyataan, dan ilustrasi yang disajikan di awal pembelajaran merupakan stimulus pembelajaran. Ketika mahasiswa menghadapi masalah-masalah yang berkaitan dengan kehidupan mereka, maka akan timbul rasa tanggung jawab untuk menyelesaikan permasalahan 
tersebut, sehingga pada diri mahasiswa akan muncul kesadaran untuk menggali informasi yang relevan untuk menyelesaikan permasalahan yang sedang dihadapi.

Mahasiswa menggunakan buku sebagai sumber informasi untuk menyelesaikan masalah. Mahasiswa akan melakukan kegiatan investigasi bersama teman dalam kelompoknya untuk memperoleh konsep-konsep IPA yang diperlukan untuk menyelesaikan masalah. Kegiatan belajar ini mampu mengoptimalisasikan keterlibatan pengalaman fisik, pengalaman logiko-matematik, transmisi sosial, dan pengaturan diri (self regulated learning). Mahasiswa mendapat kesempatan untuk berpikir reflektif dan melakukan proses pembelajaran diri melalui self-directed learning, serta mahasiswa dapat melakukan latihan proses metakognisi. Dalam pembelajaran peran dosen sebagai fasilitator dan mediator kreatif yang memberikan tanggung jawab kepada mahasiswa untuk memperoleh sendiri konsep-konsep yang diperlukan melalui interaksi dengan anggota kelompoknya (Arends, 2010:35; Barbey, 2009:37).

Model pembelajaran kuantum, memberikan kesempatan dan tanggungjawab kepada mahasiswa untuk membangun sendiri pengetahuannya dan sekaligus memanfaatkan pengetahuannya untuk menyelesaikan masalah-masalah kontekstual yang ada di sekitar lingkungannya. Hal ini membuat pembelajaran menjadi bermakna, karena mahasiswa dapat mengingat, memahami, dan menerapkan ilmu yang dipelajari, melakukan analisis, sintesis dan evaluasi terhadap segala sesuatu yang dipelajari.

Di lain pihak, model pembelajaran konvensional diawali dengan penyajian materi pelajaran yang terkait oleh dosen kepada mahasiswa. Teori, konsep, ataupun prinsip-prinsip IPA yang diharapkan dapat dikuasai oleh mahasiswa dipaparkan terlebih dahulu di depan kelas oleh dosen. Setelah itu, barulah mahasiswa dihadapkan pada permasalahan-permasalahan yang terkait dengan konsep yang telah dipaparkan. Permasalahan yang disampaikan kepada mahasiswa sama dengan permasalahan yang digunakan dalam pembelajaran kuantum, yaitu masalah-masalah aktual yang ada di lingkungan sekitar mahasiswa (kontekstual). Penyajian masalah kontekstual ini menjadikan pembelajaran IPA lebih bermakna dibandingkan dengan hanya membaca ataupun mendengarkan penjelasan dosen mengenai materi pelajaran. Namun, dalam model pembelajaran konven- sional yang menyuguhkan permasalahan kepada mahasiswa setelah mereka diberikan informasiinformasi tentang materi pembelajaran dinilai kurang konstruktivis.

Tanggung jawab mahasiswa terhadap pembelajaran dirinya sendiri menjadi kecil, sebab mahasiswa belajar hanya semata-mata karena dosen memberikan tugas kepada mahasiswa untuk mempelajari materi ajar tersebut. Hal ini akan mengurangi kemandirian mahasiswa dalam belajar untuk membentuk pengetahuannya sendiri sehingga berdampak pada kemampuan berpikir mahasiswa yang menyebabkan hasil belajar mahasiswa menjadi lebih rendah. Berdasarkan deskripsi landasan operasional teoretik tersebut, dapat dipahami bahwa MPKu lebih unggul dibandingkan dengan MPKo dalam pencapaian penalaran.

Tujuan yang kedua penelitian ini adalah untuk menguji pengaruh merangkum dengan teknik peta pikiran (TPP) dan merangkum dengan teknik konvensional (TK) dalam pencapaian penalaran. Hasil penelitian menunjukkan bahwa terdapat perbedaan yang signifikan penalaran mahasiswa antara kelompok yang merangkum dengan teknik peta pikiran (TPP) dan kelompok yang merangkum dengan teknik konvensional (TK). Pencapaian penalaran pada kelompok yang merangkum dengan teknik peta pikiran (TPP) lebih tinggi dibandingkan dengan kelompok kelompok yang merangkum dengan teknik konvensional (TK). Dengan kata lain, bahwa mahasiswa yang merangkum dengan teknik peta pikiran (TPP) lebih unggul daripada kelompok yang merangkum dengan teknik konvensional (TK) dalam pencapaian penalaran. Hal ini menunjukkan bahwa pembelajaran kuantum dan peta pikiran sejalan dengan upaya meningkatkan penalaran mahasiswa. Kemampuan penalaran merupakan unsur yang sangat penting dalam pencapaian hasil belajar (Kuhn and Dean, 2004:281; Mercer, et al., 2004:364; Zimmerman, 2007:194).

Temuan dalam penelitian ini sejalan dengan teori dan hasil penelitian yang telah dilaporkan sebelumnya. Penelitian De Porter, et al. (2003:56) juga mengungkapkan bahwa pembelajaran kuantum dan metode peta pikiran telah membawa sukses besar bagi sekolah dan anak didiknya. Meier (2000:64) menyimpulkan bahwa accelerated learning dapat membangkitkan dan menumbuhkan motivasi belajar. Kurnia (2002:97) mengungkapkan pembelajaran kuantum dapat 
meningkatkan aktivitas dan keterampilan mahasiswa dalam memahami masalah-masalah jurnalistik. Rachmawati (2004:480) melaporkan bahwa pembelajaran kuantum dapat meningkatkan hard skills dan soft skills.

Dalam model pembelajaran kuantum, mahasiswa dituntut bertanggungjawab atas pendidikan yang mereka jalani, serta diarahkan untuk tidak terlalu tergantung pada dosen. Model pembelajaran kuantum membentuk mahasiswa mandiri yang dapat melanjutkan proses belajar pada kehidupan dan karir yang akan mereka jalani, dengan demikian akan terjadi peningkatan hasil belajar mahasiswa (Buzan \& Barry, 2004:126; Hernowo, 2005:80).

Berdasarkan temuan-temuan dan paparan di atas, penelitian ini memiliki implikasi sebagai berikut: (1) Untuk mencapai penalaran secara optimal dalam pembelajaran IPA bagi mahasiswa, model pembelajaran kuantum dapat diterapkan sebagai alternatif fasilitas belajar; (2) Pembuatan peta pikiran sangat penting dilatihkan pada mahasiswa, cara ini dapat membantu mahasiswa mengorganisasikan pikirannya dan mengoptimalkan sistem kerja otak; (3) Berkaitan dengan fasilitas belajar untuk pembelajaran yang melatih kemampuan berpikir, implementasi model pembelajaran kuantum dan teknik merangkum peta pikiran harus memperhatikan tiga hal pokok yaitu aktivitas pembuatan peta pikiran, kegiatan pembelajaran, dan pelaksanaan evaluasi. Pembuatan peta pikiran hendaknya waktunya lebih lama atau dipersilakan mengerjakan di rumah sebelum materinya dibahas di kampus. Pembelajaran dimulai dengan menyajikan masalah kontekstual atau peristiwa yang dekat dengan kehidupan peserta didik. Pelaksanaan evaluasi untuk pembelajaran lebih mementingkan evaluasi yang autentik dan dilakukan secara berkesinambungan.

\section{SIMPULAN}

Berdasarkan hasil penelitian dan pembahasan, dapat disimpulkan sebagai berikut. (1) Terdapat perbedaan penalaran mahasiswa antara kelompok mahasiswa yang dibelajarkan dengan model pembelajaran kuantum dan kelompok mahasiswa yang dibelajarkan dengan model pembelajaran konvensional. Model pembelajaran kuantum memiliki pengaruh yang lebih baik dalam pencapaian penalaran mahasiswa dibandingkan model pembelajaran konvensional. (2) Terdapat perbedaan penalaran mahasiswa antara kelompok mahasiswa yang merangkum dengan teknik peta pikiran dan kelompok mahasiswa yang merangkum dengan teknik konvensional. Mahasiswa yang merangkum dengan teknik peta pikiran lebih unggul dalam pencapaian penalaran dibandingkan dengan mahasiswa yang merangkum dengan teknik konvensional. (3) Terdapat interaksi antara model pembelajaran (kuantum konvensional) dan teknik merangkum (peta pikiran dan konvensional) terhadap penalaran mahasiswa. Berdasarkan temuan penelitian ini, disarankan para pendidik (dosen dan guru) IPA dapat menggunakan model pembelajaran kuantum dan teknik merangkum peta pikiran dalam rangka meningkatkan penalaran mahasiswa. Kepada peneliti lain, diharapkan melakukan penelitian lebih lanjut yang sejenis untuk menguji konsistensi hasil penelitian ini, baik pada mata kuliah sejenis maupun mata kuliah lainnya.

\section{UCAPAN TERIMA KASIH}

Ucapan terima kasih penulis ucapkan kepada ketua lembaga penelitian Undiksha yang telah bersedia mendanai penelitian ini. Terima kasih juga disampaikan kepada pimpinan redaksi Jurnal Cakrawala atas kesediaannya menerbitkan jurnal ini.

\section{DAFTAR PUSTAKA}

A'la, M. 2010. Quantum Teaching. Yogyakarta: Diva Press.

Ardhana, W., Purwanto., Kaluge, L., \& Santyasa, I W. (2004). "Implementasi pembelajaran inovatif untuk pemahaman dalam belajar fisika di SMU", dalam Jurnal Ilmu Pendidikan, 2(11), hlm.152-168.

Arini, N. W. 2011. Implementasi metode peta pikiran berbantuan objek langsung untuk meningkatkan keterampilan menulis narasi siswa Kelas IV SD 4 Kampung Baru. Laporan Penelitian (tidak diterbitkan). Singraja: Undiksha.

Arini, N.W. \& Yani, N.P.D. 2012. Meningkatkan kreativitas dan keterampilan menulis narasi dengan menggunakan metode peta pikiran berbasis pengalaman pribadi siswa kelas IV SD No. 4 Gitgit, Sukasada, Buleleng Tahun Pelajaran 2011/2012. Laporan Penelitian (Tidak dipublikasikan). Universitas Pendidikan Ganesha. 
Arends, R.I and Kilcher, A. 2010. Teaching for student learning becoming an accomplished teacher. New York: Routledge.

Astawa, I W. P. 2004. "Meningkatkan kualitas proses dan hasil pembelajaran matematika melalui optimalisasi representasi pembelajaran dalam kerangka pembelajaran kuantum", Jurnal Pendidikan dan Pengajaran, 37(4). hlm.1-13.

Barbey, A. K. and Barsalou, L.W. 2009. "Reasoning and Problem Solving: Models", Encyclopedia of Neuroscience, vol. 8, pp.35-43.

Buzan, T. \& Barry. 2004. Memahami peta pikiran. Edisi milenium. Batam: Interaksara.

Joyce, B., Weill, M., and Calhoun, E. (2009). Models of teaching. Eight edition. New Jersey: Allyn \& Bacon.

Candiasa, I M. 2004. Statistik Multivariat Dilengkapi Aplikasi dengan SPSS. Singaraja: Unit Penerbitan IKIP Negeri Singaraja

Campbell, D. T., \& Stanley, J. C. 1996. Experimental and quasi-experimental designs for research. Chicago: Rand Menally Company.

Clayton, K., Blumberg, F., and Auld, D. P. 2010. "The relationship between motivation, learning strategies and choice of environment whether traditional or including an online component", British Journal of Educational Te chnology, 41(3), hlm.349364.

Degeng, I N.S. 2001. Landasan dan Wawasan Kependidikan. Malang: Lembaga Pengembangan dan Pendidikan (LP3) Universitas Negeri Malang.

De Porter, B \& Hernacki, M. 2003. Quantum learning: Membiasakan Belajar Nyaman dan Menyenangkan. Bandung: Kaifa.

De Porter, B. 2008. Accelerated learning. http: // www. newhorizons.org/ strategies /accelerated/deporter. htm, diakses 15 Desember 2008.
Fullan, M. 2005. Change forces the sequel. London and New York: Routledge Falmer.

Gardner, H. 1999. The Discipline Mind: What All Students Should Understand. New York: Simon \& Schusteer Inc.

Giere, R.N., Bickle, J., dan Mauldin, R.F. 2006. Understanding Scientific Reasoning, 5th edition, Belmont, CA: Thomson/Wadsworth.

Goel, V. 2005. Cognitive neuroscience of deductive reasoning. In: Holyoak K.J. and Morrison, R.G. (eds.) Cambridge Handbook of Thinking and Reasoning, pp. 475-492. New York: Cambridge University Press.

Green, A.E., Fugelsang J.A., and Kraemer D.J.M. 2006. "Frontopolar cortex mediates abstract integration in analogy", Brain Research 1096, hlm.125-137.

Hernowo. 2005. Quantum writing. Bandung: Mizan Learning Center.

Herdian. 2009. Model Pembelajaran Kuantum, (Online), (http://her-dy07.wordpress. com/2009/04/29/model-pembelajaranquantum/, diakses 24 Mei 2011).

Holyoak, K. J. 2005. Analogy. In: Holyoak K.J. and Morrison R.G. (eds.) Cambridge Handbook of Thinking and Reasoning, pp. 117-142. New York: Cambridge University Press.

Konsorsium Pendidikan Indonesia. 2010. Pendidikan IPA. tersedia pada http://pendidikanIPA.blogspot.com/2008_09_01_archive. html, diakses tanggal 1 September 2010.

Kurnia, S.S., 2002. "Quantum Learning Bagi Pendidikan Jurnalistik. (Studi Pembelajaran Jurnalistik yang Berorientasi pada Life Skill)", Jurnal Pendidikan dan Kebudayaan, 8(034), hlm.96-121.

Kuhn, D. and Dean, D. 2004. "Connecting scientific reasoning and causal inference", Journal of Cognition and Development, 5. hlm.261-288. 
Krulik, S. \& Rudnick, J. A. 1996. The new source book for teaching reasoning and problem solving in Junior and Senior High School. Boston: Allyn and Bacon.

Marzano, R.J., Brandt, R.S., Hughes, C.S., Jones, B.F., Presseisen, B.Z., Rankin, S.C., \& Suhor, C. 1988. Dimensions of thinking: $A$ framework for curriculum and instructon. Alexandria, Virginia: Association for Supervision and Curriculum Development.

Mercer, N., Dawes, L., Wegerif, R., and Sams, C. 2004. "Reasoning as a scientist: ways of helping children to use language to learn science", British Educational Research Journal, 30(3), hlm.359-378.

Meier, D. 2000. The accelerated learning handbook. Bandung: Kafia.

Nilan, P. 2009. "Indonesia: New Directions in Educational Research", Jurnal Ilmiah Pendidikan dan Pembelajaran, 6(2), hlm.1141-1296.

Nurhadi., Yasin, B., \& Senduk, A.G. 2004. Pembelajaran Kontekstual dan Penerapannya dalam KBK. Malang: Universitas Negeri Malang.

Pring, R. 2005. Philosophy of education: Aims, theory, commen sense and research. New York: Continuum.
Rachmawati, R. 2012." The implementaton quantum teaching method of graduate through up-grade hard skill and soft skill", Procedia-Social and Behavioral Sciences, 57, hlm.477-485.

Suarjana, I M. dan Japa, I G.N. 2012. Pengaruh pembelajaran kuantum berorientasi pemecahan masalah matematika terbuka terhadap penalaran mahasiswa Jurusan PGSD FIP Undiksha. Laporan penelitian (tidak dipublikasikan). Universitas Pendidikan Ganesha.

Suarjana, I M. 2013. Pengaruh model pembelajaran kuantum berorientasi PMRI terhadap pemahaman konsep dan hasil belajar matematika mahasiswa. Laporan penelitian (tidak dipublikasikan). Universitas Pendidikan Ganesha.

Wiratma, I G. L. 2010. "Politik pendidikan dalam pengembangan kesadaran Kritis dan jati diri”, Jurnal IKA, 8(2), hlm.107-122.

Wedell, M. 2009. Planning for educational change: Putting people and their contexts first. New York: Continuum.

Zimmerman, C. 2007. "The development of scientific thinking skills in elementary and middle school", Developmental Review, 27, hlm.172-223. 